\title{
Whey Protein Supplement: An Exclusive Food or Need of the Hour: Review
}

\author{
Sonia Sangwan ${ }^{1 *}$ and Raman Seth ${ }^{1}$ \\ ${ }^{1}$ Dairy Chemistry Division, ICAR-National Dairy Research Institute, Karnal-132001 (Haryana), India.
}

Authors' contributions

This work was carried out in collaboration between both authors. Both authors read and approved the final manuscript.

Article Information

DOI: 10.9734/ARRB/2021/v36i430367

Editor(s):

(1) Dr. Gonzalo Emiliano Aranda Abreu, Veracruzana University, Mexico.

Reviewers: Switzerland.

(2) Wendel Paulo Silvestre, University of Caxias do Sul, Brazil. Complete Peer review History: http://www.sdiarticle4.com/review-history/67130

\section{Review Article}

Received 05 February 2021 Accepted 13 April 2021 Published 01 May 2021

\begin{abstract}
Background: Protein is an essential portion of food that exerts beneficial effects on body composition and metabolism. However, protein-rich foods are costly and scarcely available in developing countries, and protein deficiency is a significant public health concern. In this situation, searching for additional dietary protein sources is of utmost importance due to decreasing resources because of the growing global population. The current literature review is about whey protein as it is the cheapest, readily available protein source.

Methods: Milk is formed of two proteins, casein and whey. Whey is different from the casein in milk and is formed as a by-product of the cheese-making process. Whey (the liquid left after milk curdling) was deemed a waste by the dairy industry for decades. However, it is the cheapest protein source for the poor growing populations in developing countries. Whey protein is a complete protein as it contains all nine essential amino acids. It is low in lactose content.

Conclusion: Human body cannot make essential amino acids, so it is necessary to get enough of them from the diet. Due to the availability of carbohydrates, fat, immunoglobulins, lactose, and minerals, including essential amino acids in whey protein, it is necessary for human energy. There are many benefits related to whey protein consumption, such as muscle building and loss of fat. New possible therapeutic properties of whey protein have to be investigated further for the full utility to humans.
\end{abstract}

Keywords: Whey protein; milk; casein; cheapest protein. 


\section{INTRODUCTION}

Milk is a significant source of nutrition that is widely consumed for human health. This can be obtained from several domesticated animals like sheep, goat, buffalo, and cow. Fresh cow milk contains $3.5 \%$ total protein, $80 \%$ casein, $20 \%$ whey protein, vitamins, and lipids. These ingredients are essential for growth [1,2]. In other words, milk is a source of energy (carbohydrate), lactose (sugar), nitrogen (protein; subcomponents of micro fractions), and calcium (for bones) $[3,4]$. The dairy industry was treating whey (the liquid left after milk curdling) waste for decades. As whey liquid is highly organic with high biological oxygen demand, its disposal is complicated.

On the other hand, whey is full of biologically active components, e.g., lactoferrin, lactoperoxidase, lysozyme, and immunoglobulins, etc. and is having antimicrobial properties $[3,4]$. Milk is formed of two proteins, casein and whey. Whey protein is often separated from the casein in milk or created as a by-product of cheese making. It is beneficial in wound healing due to high protein contents, weight loss as no fat, in infant health as full of amino acids. It is an excellent protein for all age groups, especially for marasmus children, and maintains their health $[5,6]$. The human body cannot make essential amino acids, so it is vital to get enough of them from the diet. Due to the availability of carbohydrates, fat, immunoglobulins, lactose, and minerals, including essential amino acids in whey protein, it is a vital source of domesticated animals' energy [7].

Whey protein may be a popular fitness and dietary supplement. It is prepared from whey, which is the liquid that separates from milk during the cheese-making process. Whey protein powder can be prepared by drying filtered whey liquid. Whey protein may be a popular choice among athletes, fitness enthusiasts, and other people eager to build muscle or reduce fat. Studies show it can help recovery from exercise, muscle building and even help lose weight by reducing appetite and boosting metabolism $[2,3,4]$. The whey protein can be taken by mixing it with water or with another liquid of choice. Despite its health benefits, some people are concerned about their safety. Whey protein concentration is different in different animals as sheep and goats have similar concentration but higher than bovine (cow) whey.
These days, industries present whey protein as a health supplement in place of various health food and beverages. These proteins are used for medicinal purposes and improve the health status of all age groups of humans. This protein is usually involved in controlling or maintaining blood glucose levels and provides additional benefits, including weight management [8]. Whey liquid is obtained from the milk of different domesticated animals, and then whey liquid is purified by removing several constituents (Saito T. [9]. There are three types of whey, i.e., whey protein concentrate (WPC; the low but still substantial level of fat and cholesterol; higher bioactive components), whey protein isolate (WPI; remove fat and lactose content but lower in bioactivated combinations), and whey protein hydrolysate (WPH; pre-digested and hydrolyzed; hydrolyzed whey could also be less allergenic) (Fig. 1). Besides, there are many immunological components in whey protein $[5,6,7,8,9]$.

Amino acid content is an essential factor in bovine milk proteins, especially caseins and whey protein. In contrast, milk protein is a potential source of immunobiologically active peptides full of nutritional value. Whey protein provides all those essential amino acids which a human cannot produce itself within the body. These amino acids are nine in number with a different function. These amino acids fullfil all body requirements and keep the body fit with lean muscle mass [10,11]. Branched-chain amino acids, e.g., leucine, isoleucine, and valine, are also present in whey. These branched-chain amino acids help in protein synthesis and thus cover up to one-third of muscle protein. These amino acids are not broken in the liver, whereas other amino acids are broken by the gut and the liver. Consuming these branched-chain amino acids before physical workup can upsurge uptake into the muscle tissue and provides many profits, e.g., enhanced growth hormone circulation, lower lactate levels and better muscular oxidation. Branched-chain amino acids consumption also decrease serum concentrations of intramuscular enzymes creatine kinase and lactate dehydrogenase, etc. $[12,13]$. The branched amino acids are released from the liver and other internal organs to skeletal muscle. Branched-aminoacids can control blood sugar levels. Thus about $40-50 \%$ of blood sugar during exercise is produced with branched amino acids $[12,13]$. 


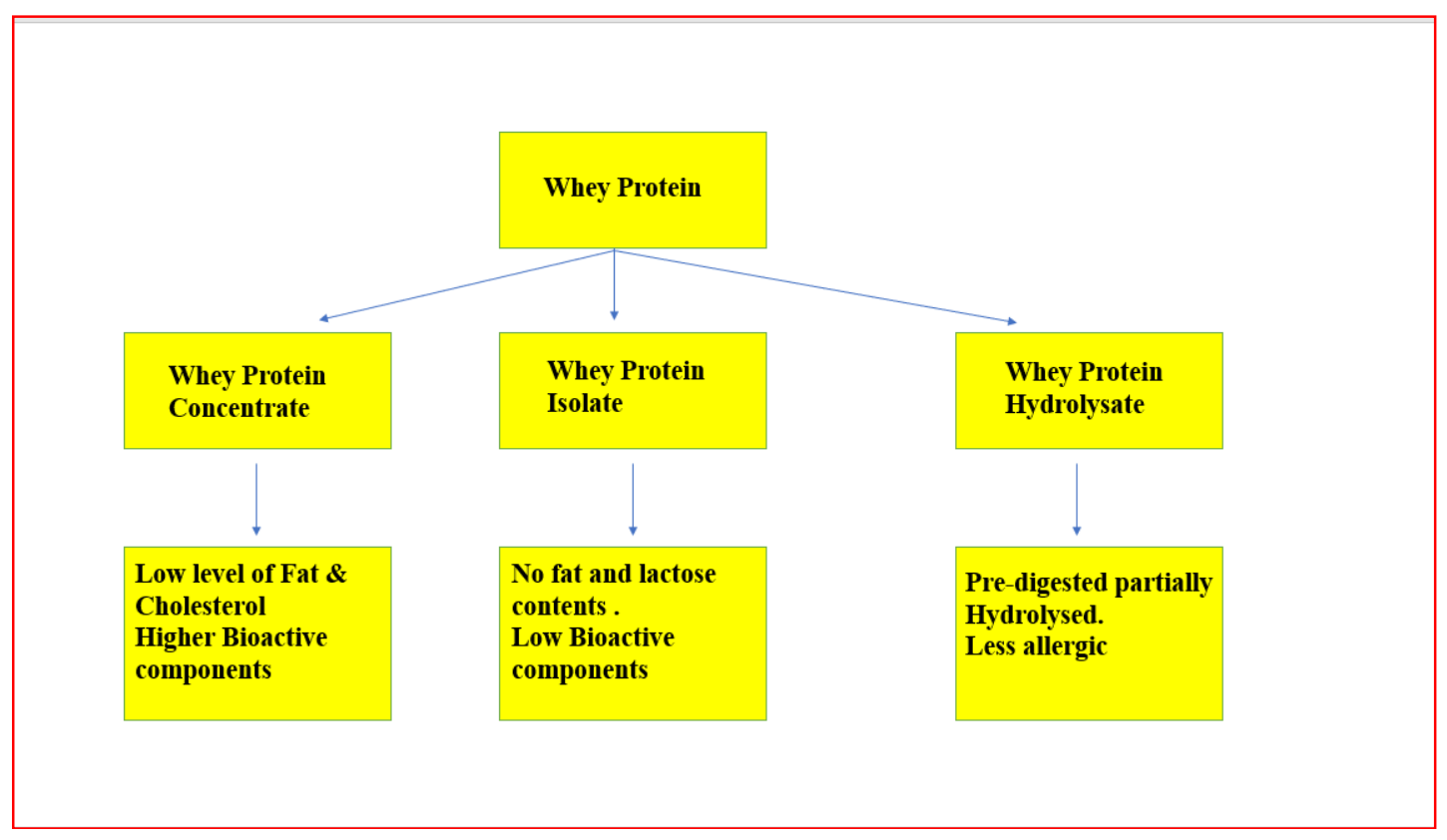

Fig. 1. Benefits of whey protein

Cysteine and methionine, which help to grow immune function through intracellular conversion to glutathione, are present in high whey protein concentrations [14]. Lactoferrin (iron-binding glycoprotein) comprises 689 amino acid residues and its strength in human milk is $2 \mathrm{mg} / \mathrm{ml}$, and colostrums are $7 \mathrm{mg} / \mathrm{ml}$. Whereas in bovine milk $(0.2 \mathrm{mg} / \mathrm{ml})$ and colostrums $(1.5 \mathrm{mg} / \mathrm{ml})$, respectively [15]. The lactoferrin acts as an antimicrobial and anti-inflammatory agent and can induce natural killer cells and colonystimulating factors, including macrophages' activation[16]. In small children less than two years of age, lactoferrin is delivered through breast milk. Nowadays, bovine lactoferrin, including recombinant human lactoferrin, is obtainable commercially and is usually added to various food products, including milk, useful for the immune system. The lactoferrin possesses antibacterial and antiviral activities in the intestine against multiple pathogens. Besides, it may regulate infants and pregnant women's iron content via a receptor-mediated pathway [16].

Whey protein also contains immunoglobulins (blood group proteins) that are useful for enhancing immunity. The highest concentration of these immunoglobulins is present in colostrum (first milk after birth). The immunoglobulins help control various bacterial infections and present in the form of various antibodies, i.e., $\lg G, \lg M, \lg A$, secretory IgA andlg [17]. These immunoglobulins deliver passive maternal immunity to infants through breast milk and help to maintain our immune system. These immunoglobulins are about $10-15 \%$ of total whey proteins from bovine milk [17]. The colostrum of cow, sheep, and bovine is full of lactoferrin [16]. Bovine milk contains the enzyme lactoperoxidase, which has antibacterial properties against many pathogens. This enzyme, in combination with hydrogen peroxide $\left(\mathrm{H}_{2} \mathrm{O}_{2}\right)$ and thiocyanate $\left(\mathrm{SCN}^{-}\right)$, works as an antimicrobial agent in raw milk samples $[18,19,20]$. Whey contains lactalbumin, one of the significant milk serum proteins, i.e., alphalactalbumin, which has antiproliferative effects in human cell lines adenocarcinoma as Caco-2 and HT29. The content of alpha-lactalbumin is much higher in cow's milk and may cause an allergic reaction in some cases $[21,22]$. Goat milk free of allergic reaction is thus useful in young children. The concentration of alpha-lactalbumin is different in different animals, e.g., cow (52.9-53.6 $\%)$, sheep $(8.97-17 \%)$, and goat $(13.31-34.7 \%)$ $[21,22,23]$

\section{VARIOUS HEALTH BENEFITS OF WHEY PROTEINS}

Whey protein is a cheap and readily available protein source in developing countries like India. It is full of many benefits to human beings in its various derivative forms (concentrate, isolate, and hydrolysate). 


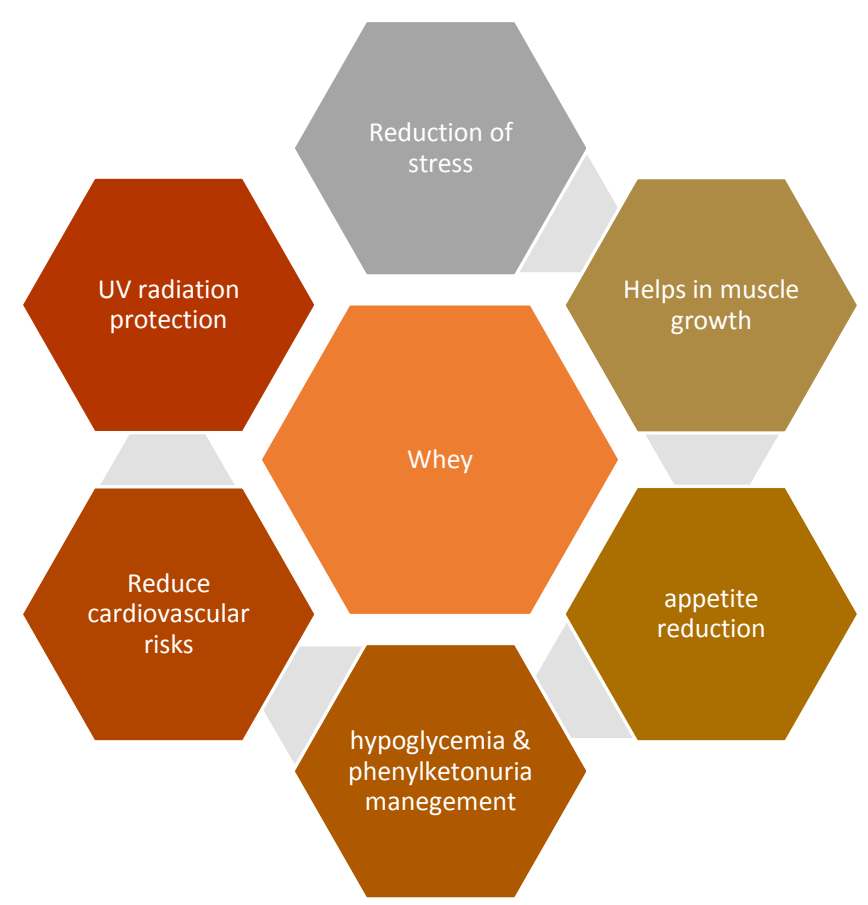

Fig. 2. Showing the health benefits of whey proteins in various forms

\subsection{Gut and Prebiotic Action}

In seriously ill patients, the gut does not function appropriately and becomes unable to absorb even a bland diet. This affects the health of patients. It is not possible to give parenteral nutrition to all such patients due to high cost. In these patients, whey protein protection might impart inflammation and enhance enteral nutrition [23]. To exert their therapeutic property, lactic acid bacteria and yeast need to be viable. The prebiotic action of whey on the gut may be not that effective due to the hostile gastrointestinal environment and whey storage. Whey protein gels can encapsulate the protecting the microbes, and its efficacy is more against the adverse conditions. The encapsulating Lactobacillus rhamnosus CRL 1505 in whey protein and pectin survive better at low $\mathrm{pH}$. Similarly, pectin beads with a whey protein layer could be used as a probiotic carrier in acidic functional foods [24].

Lactobacillus acidophilus and Bifidobacterium in yoghurt beverages are stabilized with highmethoxyl pectin and whey protein concentrate [25]. This proves the role of whey as a probiotic and prebiotic stabilizer. Whey protein isolate and alginate microparticles have shown suitability as oral delivery systems for probiotic yeast Saccharomyces boulardii [26].

\subsection{Muscle Strengthening}

All eccentric and concentric skeletal muscle exercises result in muscle damage and produce inflammatory markers (muscle proteins in the blood) [27]. The anabolic protein hydrolysates and amino acid supplements accelerate the repair. Leucine-derived metabolite $\beta$-hydroxy- $\beta$ methyl butyrate ingestion results in the healing of muscle injury. Resistance exercise, such as weight-lifting, raises oxidation products in plasma disturbs leukocyte redistribution and leukocyte functionality [28]. The whey protein diet is better than the casein diet to heal injuries sustained due to isometric and concentric exercises. [29]. The low-protein $(6.25 \mathrm{~g})$ beverage can be as effective as a high-protein dose $(25 \mathrm{~g})$ at stimulating myofibrillar protein synthesis rates when supplemented with a high $(5 \mathrm{~g})$ leucine content [30]. Leucine, an amino acid (10\% of the total whey amino acid), is essential for muscle hypertrophy. Health parameters, performance, and body composition effects produced by a 12week intake of hydrolyzed whey protein were compared in players. Ingestion of the hydrolyzed whey protein helped drop in the muscle damage markers (creatine kinase and lactate dehydrogenase) [31]. Lean body mass gains are significantly high in whey protein consumers than soy protein, and the good response was correlated with the elevated levels of leucine and faster absorption. [32]. 


\subsection{Immunomodulator Action}

Whey protein concentrates enhance essential mucosal immunity during early life and has a protective role in some immune disorders [33]. The infants may suffer from atopic dermatitis as being a major vulnerable group. A meta-analysis of the systematic review revealed that atopic dermatitis incidence was considerably lower among infants in the partially hydrolyzed wheybased formula group than the bovine milk group [34]. The finding suggested that whey-based formula might protect infants from atopic dermatitis. Psoriasis is chronic autoimmune disease-causing thick skin, dry scales, and red patches. Bioactive whey protein isolate can decrease systemic inflammation due to psoriasis by increasing glutathione levels. The intake of $20 \mathrm{~g} /$ day whey protein isolates improved the Psoriatic patients [35].

\subsection{Antioxidant Action}

Inflammatory or oxidative stress can cause cystic fibrosis, pneumonia, diabetes, cancer, atherosclerosis, myocardial infarction, ageing, and many other degenerative diseases [36]. Whey is full of the antioxidant glutathione and can eradicate the adverse effects of the stressors. Hyperbaric treatment of whey protein accelerated the release of bioactive peptides, raised intracellular glutathione levels, and decreased the in vitro generation of interleukin IL-8, a cytokine responsible for respiratory tract diseases [37]. The dietary supplementation of pressurized whey $(20 \mathrm{~g} / \mathrm{day})$ in cystic fibrosis patients decreases serum C-reactive protein level significantly [38]. The antioxidant and antiinflammatory effects of pressurized whey protein isolate and native hydrolysate in human epithelial colorectal adenocarcinoma Caco-2 cells exposed to $\mathrm{H}_{2} \mathrm{O}_{2}$ were compared [37]. The results suggested that whey protein isolate hydrolysates can lessen inflammation and oxidative stress in intestinal cells exposed to oxidative injury. The consumption of whey protein hydrolysate boosts HSP70 expression [38]. Thus the whey protein hydrolysate can enhance cell survival factors such as HSP90 and vascular endothelial growth factor (VEGF) [40]. Pressurized whey protein can decrease the level of the inflammatory response, oxidative stress, and lung damage. Thus whey protein subjected to hyperbaric treatment has superior biological quality. It protects the airway proteins from oxidation and stimulates leukocytes to kill the pathogens, thus saving them from Pseudomonas aeruginosa [41]. Whey protein

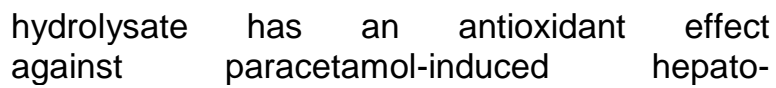
nephrotoxicity [5].

\subsection{Anticancer Action}

Several studies have suggested that whey protein hydrolysate may help treat cancer patients and improve colon cancer anticancer efficacy $[42,43,44]$. A 48-year-old female patient with increased serum levels of leucine, isoleucine, valine, lysine, and threonine was administered with whey protein (10 g thrice daily) and a weekly intramuscular injection of testosterone enanthate before and during the standard-of-care (SOC) chemotherapy. As a result of the combination therapy, improved lean body mass, physical activity, and overall quality of life were observed in recurrent cervical cancer [45].

\subsection{Cardioprotective}

Whey protein intake reduces cardiovascular disease (ischemic stroke) risk. Whey-derived extract (NOP-47) ingestion increased impaired brachial artery flow-mediated dilation (improved endothelial function). Postprandial plasma amino acids level increased. Arterial dilation improvement was independent of circulating vasoactive compounds such as nitric oxide, prostacyclin, and endothelium-derived hyperpolarizing factors. The cardiovascular risk might be lessened by using rapid-absorbable extracts derived from whey $[46,47]$.

\subsection{Antidiabetic Action}

Diabetes affects all human organs accompanied by many complications such as loss of vision, angiopathy, reduced blood flow leading to tissue hypoxia, and nonhealing ulcers [48]. Type-2 diabetes is managed by diet control and hypoglycaemic drugs. Whey protein has been demonstrated to reduce serum glucose levels in healthy individuals, maintain muscle mass, boost the release of satiety hormones (cholecystokinin, leptin, and glucagon-like peptide 1 (GLP-1)) and lower the secretion of the hunger hormone ghrelin [49]. For ancillary therapy in glycemia and vascular inflammation control in people with diabetes, cysteine in whey proteins is very useful [50].

The whey protein helps in diabetic wound healing by restricting inflammatory cytokines' access by maintaining standard IL-10, TNF- $\alpha$, IL-1 $\beta$, and IL- 
6 levels. Higher serum levels of leucine, isoleucine, valine, lysine, and threonine help in Insulin secretion in the body $[51,52]$.

Whey protein fractions (whey isolate and whey hydrolysate) added to a fat-rich meal lowered postprandial triglyceride responses in type 2 diabetic subjects. Both components provoked a higher insulin response [53]. A hydrolyzed whey protein-based supplement may result in a higher leucine level, followed by an increased Insulin level [54].

\subsection{Obesity Management}

Whey protein helps in the reduction of obesity. The ameliorating effects of the protein-rich diet on metabolic disorders are precisely due to the modulation of satiety mediated by liver lipogenesis attenuation [55]. The whey protein concentrate employs more substantial beneficial effects than that of soy protein isolate on appetite, calorie intake, anthropometry (body mass index and waist circumference), and body composition (body fat mass and lean muscle) of obese men and thus reduce obesity [56].

\subsection{Side Effects of Whey Protein}

Whey protein is a beneficial nutritional food, and there is no other natural protein equivalent to this. Still, there can be risks from nutritionally refined foods such as whey, as it is a heavy protein. Acne can develop if a person takes whey protein for a long time. Most whey protein's side effects are related to digestion and may experience bloating, gas, stomach cramps, and diarrhoea. However, most of these side effects are due to lactose intolerance. It is due to a deficiency of the enzyme lactase needed for lactose digestion.

Moreover, lactose intolerance is quite common, and about $75 \%$ of people are affected worldwide. In such cases, whey protein isolate powder can be used as a whey protein isolate is more refined. It holds a smaller amount of fat and lactose than whey protein concentrate.

People with a cow's milk allergy may be allergic to whey protein. Cow milk allergy exists up to the initial three-year age, and after that, $90 \%$ of people outgrow cow's milk allergies. A cow's milk allergy symptoms are hives, rashes, facial swelling, throat, tongue swelling, a runny or stuffy nose, and rarely anaphylaxis, a severe, lifethreatening allergic reaction $[57,58]$.

\subsection{Interaction with Drugs}

Levodopa-Whey protein interferes with the absorption levodopa and thus decrease the effectiveness of levodopa. So, avoid taking whey protein and levodopa together.

Albendazole -Whey protein interferes with absorption and can decrease albendazole absorption in the body and decrease albendazole's effectiveness. So avoid taking both together.

Alendronate (Fosamax)-Whey protein can decrease the absorption and effectiveness of alendronate. So, avoid taking whey protein within two hours of taking alendronate (Fosamax).

Antibiotics (Quinolone antibiotics). Whey protein and antibiotics should not be taken together due to decreased absorption. Do not take whey protein supplements and tetracycline together, and a gap of one hour is essential. Other antibiotics that might react with whey protein are Quinolone antibiotics such as ciprofloxacin, norfloxacin, sparfloxacin, etc.

Antibiotics (Tetracycline antibiotics)- As whey protein contains calcium that can attach to tetracyclines in the stomach and decrease tetracyclines' absorption. To avoid this interaction, take whey protein four hours after taking tetracyclines $[57,58]$

\section{A FEW REASONS NOT TO TAKE WHEY PROTEIN [59]}

1. Lactose - Whey protein supplements (WPC) still retain lactose, which leads to digestive distress if there is lactose intolerance.

2. Unintended weight gain- Whey protein contains sugars and fat in addition to protein. The accumulative ratio of macronutrients like sugars and fat add extra calories to a normal diet. Thus, there is extra addition of calories in the body that causes unplanned weight gain over time.

3. High Cost - whey protein products are relatively more costly than whole foods such as tuna, peanut butter and skim milk which is an economical supplement equivalent to whey protein.

4. Lack of Nutrients - Whey protein supplements contain lower levels of 
essential nutrients like zinc, iron, vitamins, omega 3 and fibres that many whole food sources of protein provide.

5. Contaminants - In India,dietary supplements do not undergo the same regulation before being sold over-thecounter in the open market or online purchase, unlike conventional foods. Whey protein supplements may get exposed to certain contaminants, impurities or banned ingredients [59].

\section{CONCLUSION}

Whey protein is an essential and economical protein source full of nine amino acids and branched amino acids. So, it is a first-rate nutrient. Only whey protein can fulfil the increasing demand for an economical protein source for humans in developing nations. Excess of everything is bad, so is whey protein. Whey protein is full of immunoglobulins and can challenge cancer as an immune nutrient. Still, whey is an underutilized resource, and new strategies should be planned to increase its utility for human welfare.

\section{COMPETING INTERESTS}

Authors have declared that no competing interests exist.

\section{REFERENCES}

1. Foegeding EA, Davis JP, Doucet D, McGuffey MK. Advances in modifying and understanding whey protein functionality. Trends in Food Science \& Technology. 2002;13(5):151-159.

2. Marshall K. Therapeutic applications of whey protein. Alt Med Rev. 2004;9(2):136156.

3. Lollo PC, Farfan AJ, de Carvalho-Silva LB. Physiological and physical effects of different milk protein supplements in elite soccer players. J Hum Kinet. 2011;30:4957.

4. Josse AR, Phillips SM. Impact of milk consumption and resistance training on body composition of female athletes. Med Sport Sci. 2012;59:94-103.

5. Athira S, Mann B, Sharma R, Kumar R. Ameliorative potential of whey protein hydrolysate against paracetamol-induced oxidative stress. J Dairy Sci. 2013; 96:1431-1437.
DOI:10.3168/jds.20126080.[PubMed] [Cross Ref]

6. Xu R, Liu N, Xu X, Kong B.Antioxidative effects of whey protein on peroxide induced cytotoxicity. J Dairy Sci.2011; 94(8):3739-3746.

7. Blome RM, Drackley JK, McKeith FK, Hutjens MF, McCoy GC. Growth, nutrient utilization, and body composition of dairy calves fed milk replacers containing different amounts of protein. J Anim Sci.2003;81(6):1641-1655.

8. Mortensen LS, Hartvigsen ML, Brader LJ, Astrup A, Schrezenmeir J, et al. Differential effects of protein quality on postprandial lipemia in response to a fat-rich meal in type 2 diabetes: Comparison of whey, casein, gluten and cod protein. Am J ClinNutr.2009;90(1):41-48.

9. Saito T. Antihypertensive peptides derived from bovine casein and whey proteins. AdvExp Med Biol. 2008;606:295-317.

10. Coker RH, Miller S, Schutzler S, Deutz N, Wolfe RR. Whey protein and essential amino acids promote the reduction of adipose tissue and increased muscle protein synthesis during caloric restrictioninduced weight loss in elderly, obese individuals. Nutr J.2012;11:105.

11. Burd NA, West DW, Moore DR, Atherton PJ, Staples AW, et al. Enhanced amino acid sensitivity of myofibrillar protein synthesis persists for up to $24 \mathrm{~h}$ after resistance exercise in young men. $J$ Nutr.2011;141(4):568-573.

12. De Bandt JP, Cynober L. Therapeutic use of branched-chain amino acids in burn, trauma, and sepsis. J Nutr.2006;136(30): 8S-13S.

13. Luigi F, Nicole EC, Apelo A, Sebastian I, Joshua CN, et al. Decreased consumption of branched-chain amino acids improves metabolic health. Cell Rep.2016;16(2): 520-530.

14. Grimble RF, Grimble GK.Immunonutrition: role of sulfur amino acids, related amino acids, and polyamines. Nutrition.1998; 14(7-8):605- 610.

15. Gupta A, Chaphalkar SR. Quantitative estimation of lactoferrin and leukocytes contents in bovine, sheep, and goat samples. J Adv Food Sci Tech.2016;3(1): 21-24.

16. Gupta A, Chaphalkar SR. Flow cytometric estimation of lactoferrin content in bovine milk samples. J Adv Food Sci Tech.2016; 3(1):36-40. 
17. Bell SJ. Whey protein concentrates with and without immunoglobulins: a review. J Med Food.2000;3(1):1-13.

18. Steele WF, Morrisons M.Antistreptococcal activity of lactoperoxidase. $J$ Bacteriol.1969;97(2):635-639.

19. Björck L, Rosen CG, Marshall V, Reiter B. Antibacterial activity of lactoperoxidase system in milk against pseudomonas and other gram-negative bacteria. ApplMicrobiol.1975;30(2):199-204.

20. Shin K, Hayasawa H, Lönnerdal B. Purification and quantification of lactoperoxidase in human milk with use of immunoadsorbents with antibodies against recombinant human lactoperoxidase. Am J ClinNutr. 2001;73(5):984-989.

21. Kelleher SL, Chatterton D, Nielsen K, Lönnerdal B.Glycomacropeptide and alpha-lactalbumin supplementation of infant formula affects growth and nutritional status in infant rhesus monkeys. Am J ClinNutr.2003;77(5):126-128.

22. Ren J. Alpha-lactalbumin possesses a distinct zinc-binding site. $J$ Biol Chem.1993;268(26):19292-19298.

23. Abrahão V. Nourishing the dysfunctional gut and whey protein. CurrOpinClinNutrMetab Care. 2012;15:480-484.

DOI:10.1097/MCO.0b013e328356b71e. [P ubMed] [Cross Ref]

24. Gerez CL, Font de Valdez G, Gigante ML, Grosso CRF. Whey protein coating bead improves the survival of the probiotic Lactobacillus rhamnosus CRL 1505 to low pH.LettApplMicrobiol. 2012;54:552556.

DOI:10.1111/j.1472-

765X.2012.03247.x. [PubMed] [Cross Ref]

25. Walsh $\mathrm{H}$, Cheng J, Guo M. Effects of carbonation on probiotic survivability, physicochemical, and sensory properties of milk-based symbiotic beverages. J Food Sci. 2014;79:M604-M613.

DOI: $\quad 10.1111 / 1750-$

3841.12381. [PubMed] [Cross Ref]

26. Hébrard $G$, Hoffart V, Beyssac $E$, et al. Coated whey protein/alginate microparticles as oral controlled delivery systems for probiotic yeast. J Microencapsul. 2010;27:292-302. DOI:10.3109/02652040903134529. [PubM ed] [Cross Ref]

27. Morton JP, Kayani AC, McArdle A, Drust $B$. The exercise-induced stress response of skeletal muscle, with specific emphasis on humans. Sports Med. 2009;39:643662.

DOI: $\quad 10.2165 / 00007256-200939080-$ 00003. [PubMed] [Cross Ref]

28. Freidenreich DJ, Volek JS. Immune responses to resistance exercise. Exerc. Immunol Rev. 2012;18:8-41. [PubMed]

29. Martin V, Ratel S, Siracusa J, et al. Whey proteins are more efficient than casein in the recovery of muscle functional properties following a casting induced muscle atrophy. PLoS One. 2013;8: e75408.

DOI: 10.1371/journal.pone.0075408. [PMC free article] [PubMed] [Cross Ref]

30. Churchward-Venne TA, Breen L, Di Donato DM, et al. Leucine supplementation of a low-protein mixed macronutrient beverage enhances myofibrillar protein synthesis in young men: a double-blind, randomized trial. Am J ClinNutr. 2014;99:276-286.

DOI:10.3945/ajcn.113.068775. [PubMed][ Cross Ref]

31. Lollo PCB, Amaya-Farfan J, Faria IC, et al. Hydrolyzed whey protein reduces muscle damage markers in brazilian elite soccer players compared with whey protein and maltodextrin. A twelve-week inchampionship intervention. Int Dairy $\mathrm{J}$. 2014;34:19-24.

DOI: 10.1016/j.idairyj.2013.07.001.[Cross Ref]

32. Volek JS, Volk BM, Gómez AL, et al. Whey protein supplementation during resistance training augments lean body mass. J Am CollNutr. 2013;32:122-135.

DOI:10.1080/07315724.2013.793580.[Pub Med] [Cross Ref]

33. Pérez-Cano FJ, Marín-Gallén S, Castell M, et al. Bovine whey protein concentrate supplementation modulates maturation of immune system in suckling rats. $\mathrm{Br} \mathrm{J}$ Nutr. 2007;2:98(Suppl 1):S80-S84.[PubMed]

34. Alexander DD, Schmitt DF, Tran NL, et al. Partially hydrolyzed $100 \%$ whey protein infant formula and atopic dermatitis risk reduction: a systematic review of the literature. Nutr Rev. 2010;68:232-245.

DOI: $\quad 10.1111 / \mathrm{j} .1753-$

4887.2010.00281.x. [PubMed] [Cross Ref]

35. Prussick R, Prussick L, Gutman J. Psoriasis improvement in patients using glutathione-enhancing, nondenatured whey protein isolate: A pilot study. J ClinAesthetDermatol. 2013;6:23-26.[PMC free article] [PubMed] 
36. Essick EE, Sam F. Oxidative stress and autophagy in cardiac disease, neurological disorders, aging, and cancer. Oxidative Med Cell Longev. 2010;3:168-177.

DOI: 10.4161/oxim.3.3.12106.[PMC free article] [PubMed] [Cross Ref]

37. Piccolomini AF, Iskandar MM, Lands LC, Kubow S. High hydrostatic pressure pretreatment of whey proteins enhances whey protein hydrolysate inhibition of oxidative stress and IL-8 secretion in intestinal epithelial cells. Food Nutr Res; 2012. [PMC free article] [PubMed]

38. Lands LC, Iskandar M, Beaudoin $\mathrm{N}$, et al. Dietary supplementation with pressurized whey in patients with cystic fibrosis. J Med Food. 2010;13:77-82.

DOI:10.1089/jmf.2008.0326. [PubMed][Cro ss Ref]

39. De Moura CS, Lollo PCB, Morato PN, et al. Whey protein hydrolysate enhances the exercise-induced heat shock protein (HSP70) response in rats. Food Chem. 2013;136:1350,-1357.

DOI:10.1016/j.foodchem.2012.09.070. [Pu bMed] [Cross Ref]

40. Moura CS, Lollo PCB, Morato PN, et al. Whey protein hydrolysate enhances HSP90 but does not alter HSP60 and HSP25 in skeletal muscle of rats. PLoS One. 2014;9:e83437.

DOI: 10.1371/journal.pone.0083437. [PMC free article] [PubMed] [Cross Ref]

41. Kishta OA, Iskandar M, Dauletbaev N, et al. Pressurized whey protein can limit bacterial burden and protein oxidation in Pseudomonas aeruginosa lung infection. Nutrition. 2013;29:918-924.

DOI:10.1016/j.nut.2012.11.009. [PubMed] [ Cross Ref]

42. Attaallah W, Yilmaz AM, Erdoğan N, et al. Whey protein versus whey protein hydrolyzate for the protection of azoxymethane and dextran sodium sulfate induced colonic tumors in rats. PatholOncol Res. 2012;18:817-822.

DOI: $10.1007 / \mathrm{s} 12253-012-9509-9$

[PubMed] [Cross Ref]

43. Castro GA, Maria DA, Bouhallab $S$, Sgarbieri VC. In vitro impact of a whey protein isolate (WPI) and collagen hydrolysates $(\mathrm{CHs})$ on B16F10 melanoma cells proliferation. J Dermatol Sci. 2009;56:51-57.

DOI:10.1016/j.jdermsci.2009.06.016. [Pub Med] [Cross Ref]
44. Takata T, Tanaka F, Yamada $\mathrm{T}$, et al. Clinical significance of caspase-3 expression in pathologic-stage I, nonsmallcell lung cancer. Int J Cancer. 2001; 96(Suppl):54-60.

DOI: 10.1002/ijc.10347.[PubMed] [Cross Ref]

45. Dillon EL, Basra G, Horstman AM, et al. Cancer cachexia and anabolic interventions: a case report. J CachexSarcopenia Muscle. 2012;3:253263.

DOI: 10.1007/s13539-012-0066-6. [PMC free article][PubMed] [Cross Ref]

46. Ballard KD, Kupchak BR, Volk BM, et al. Acute effects of ingestion of a novel wheyderived extract on vascular endothelial function in overweight, middle-aged men and women. Br J Nutr. 2013;109:882-893. DOI:10.1017/S0007114512002061. [PubM ed] [Cross Ref]

47. SheikholeslamiVatani D, AhmadiKaniGolzar F. Changes in antioxidant status and cardiovascular risk factors of overweight young men after six weeks supplementation of whey protein isolate and resistance training. Appetite. 2012; 59:673-678.

DOI:10.1016/j.appet.2012.08.005. [PubMe d][Cross Ref]

48. Casqueiro J, Casqueiro J, Alves C.Infections in patients with diabetes mellitus: a review of pathogenesis. Indian J EndocrinolMetab. 2012;16(Suppl 1):S27S36. [PMC free article] [PubMed]

49. Sousa GTD, Lira FS, Rosa JC, et al. Dietary whey protein lessens several risk factors for metabolic diseases: a review. Lipids Health Dis. 2012;11:67.

DOI: 10.1186/1476-511X-11-67. [PMC free article][PubMed] [Cross Ref]

50. Jain SK. L-cysteine supplementation as an adjuvant therapy for type-2 diabetes. Can J PhysiolPharmacol. 2012;90:1061-1064. DOI: 10.1139/y2012-087. [PubMed] [Cross Ref]

51. Badr G, Badr BM, Mahmoud MH, et al. Treatment of diabetic mice with undenatured whey protein accelerates the wound healing process by enhancing the expression of MIP-1 $\alpha$, MIP-2, KC, CX3CL1 and TGF- $\beta$ in wounded tissue. BMC Immunol. 2012;13:32.

DOI: 10.1186/1471-2172-13-32.[PMC free article] [PubMed] [Cross Ref] 
52. Salehi A, Gunnerud U, Muhammed SJ, et al. The insulinogenic effect of whey protein is partially mediated by a direct effect of amino acids and GIP on $\beta$-cells. NutrMetab (Lond). 2012; 9:48.

DOI: 10.1186/1743-7075-9-48. [PMC free article] [PubMed] [Cross Ref]

53. Mortensen LS, Holmer-Jensen J, Hartvigsen ML, et al. Effects of different fractions of whey protein on postprandial lipid and hormone responses in type 2 diabetes. Eur J ClinNutr. 2012;66:799805.

DOI:10.1038/ejcn.2012.48. [PubMed] [Cro ss Ref]

54. Toedebusch RG, Childs TE, Hamilton SR, et al. Postprandial leucine and insulin responses and toxicological effects of a novel whey protein hydrolysate-based supplement in rats. J IntSoc Sports Nutr. 2012;9:24.
DOI: 10.1186/1550-2783-9-24. [PMC free article] [PubMed] [Cross Ref]

55. Freudenberg A, Petzke KJ, Klaus S.Dietary L-leucine and L-alanine supplementation have similar acute effects in the prevention of high-fat diet-induced obesity. Amino Acids. 2013;44:519-528. DOI:10.1007/s00726-012-1363-

2. [PubMed] [Cross Ref]

56. Tahavorgar A, Vafa M, Shidfar F, et al. Whey protein preloads are more beneficial than soy protein preloads in regulating appetite, calorie intake, anthropometry, and body composition of overweight and obese men. Nutr Res; 2014 [PubMed]

57. Available:https://www.rxlist.com/whey_prot ein/supplements.htm;

58. Available:https://www.drugs.com/mca/whe y-protein

59. OMG, No, Whey! The pros and cons of Whey Protein and its role in performance. KLU Coaching, Sept 6, 2017)

(c) 2021 Sangwan and Seth; This is an Open Access article distributed under the terms of the Creative Commons Attribution License (http://creativecommons.org/licenses/by/4.0), which permits unrestricted use, distribution, and reproduction in any medium, provided the original work is properly cited. 